\title{
The electroanalytical detection of triglyceride concentrations in olive oil using modified screen printed electrodes with ionic liquid [ I-(2-ethoxyethyl)- I-methylpyrrolidinium bis(trifluoromethylsulfonyl)imide]-lipase
}

\begin{abstract}
The electroanalytical detection of triglyceride concentrations in olive oil using modified screen printed electrodes with Ionic Liquid [1-(2-ethoxyethyl)-1-methylpyrrolidinium bis(trifluoromethylsulfonyl)imide]-lipase was reported for the first time. In this study, 1-(2-ethoxy-ethyl)-1-methylpyrrolidinium bis(trifluoromethylsulfonyl)imide, $\left[\mathrm{C}_{2} \mathrm{OC}_{2} \mathrm{C}_{1}\right.$ pyrr $]\left[\mathrm{N}(\mathrm{Tf})_{2}\right]$ was used as an ionic liquid due to the high ionic conductivity and good biocompatibility to enhance the electrochemical response. The mixture of $\left[\mathrm{C}_{2} \mathrm{OC}_{2} \mathrm{C}_{1}\right.$ pyrr $]\left[\mathrm{N}(\mathrm{Tf})_{2}\right]$-GA-Lipase was immobilized on the surface of the screen printed carbon electrodes (SPCE) by drop casting technique. The electrochemical performance and mechanism of $\mathrm{C} /\left[\mathrm{C}_{2} \mathrm{OC}_{2} \mathrm{C}_{1}\right.$ pyrr $]\left[\mathrm{N}(\mathrm{Tf})_{2}\right]$-GA-Lipase modified electrode was investigated using cyclic voltammetry (CV). The surface morphology of the modified SPCE was also studied using SEM. The optimization parameters of $\mathrm{C} /\left[\mathrm{C}_{2} \mathrm{OC}_{2} \mathrm{C}_{1}\right.$ pyrr $]\left[\mathrm{N}(\mathrm{Tf})_{2}\right]$-GA-Lipase electrodes were carried out, and shows that $\mathrm{pH} 7,30^{\circ} \mathrm{C}$ and $5 \%$ of lipase enzyme loading resulted in optimum performance. The electroanalytical methodology proposed in this manuscript was successfully applied in the determination of triglyceride concentrations in olive oil. The limit of detection (LOD) and response time were $0.68 \mathrm{mM}$ and 46 seconds respectively. A linear calibration range from 0.67 to $2.68 \mathrm{mM}$ was also obtained. Common interfering compounds on the sensor were investigated using cyclic voltammetry. Furthermore, the biosensor was effectively validated using gas chromatography analysis.
\end{abstract}

\author{
Volume 2 Issue 5 - 2017 \\ Nurul Huwaida Rosli,' Nor Monica Ahmad, \\ Mohd Azri Ab Rani,' Carlos Fernandez, \\ Zainiharyati Mohd Zain' \\ 'Universiti Teknologi MARA, Malaysia \\ ${ }^{2}$ Robert Gordon University, UK
}

Correspondence: Zainiharyati Mohd Zain, Universiti Teknologi MARA, 40450 Shah Alam, Selangor, Malaysia, Email zainihar@salam.uitm.edu.my

Received: May 29, 2017 | Published: June 15, 2017

\section{Introduction}

Triglycerides (TG) can be generated by esterification process of three hydroxyl $(-\mathrm{OH})$ groups of glycerol with three molecules of fatty acids. Triglyceride acts not only in human metabolisms but also as energy sources and dietary fat transporter. The determinations of triglyceride levels in urine, blood and food is important for clinical or medical analysis to determine the clinical disorders due to abnormal levels of triglyceride. Standard methods for triglyceride determination in serum based on fluorometric, chromatographic, and high performance liquid chromatographic (HPLC) methods are not extensively available and unsuitable for point-of-care applications due to expensive instrumentation and complicated sample pre-processing. Therefore, biosensors offer advantages for triglyceride determination due to relatively low cost, ease of use and good selectivity. The most recent reports of triglyceride biosensors found in literature ${ }^{1-3}$ are based on interactions of three enzymes, lipase, glycerol kinase (GK) and glycerol-3-phosphate oxidase (GPO). Pundir et al. ${ }^{4}$ reported an electrochemical sensor for triglyceride by measuring the oxygen consumption or the amount of hydrogen peroxide produced by the enzymatic reactions.

Pauliukaite et al. ${ }^{5}$ determined triglyceride by employing a single enzyme lipase with an ionic liquid (IL) to modify the electrode surface which resulted in a higher catalytic activity when compared to the enzyme lipase on its own without ionic liquid. Solanki et al. ${ }^{6}$ immobilized mixture of lipase/ $\mathrm{CeO}_{2}$ nanoparticles (NPs) on surface of indium tin oxide (ITO), in the absence of ionic liquid. While, Pauliukaite et al. ${ }^{5}$ immobilized mixture of lipase/1-butyl-3-methylimidazolium bis(triflouromethane) sulfonamide, $\left(\right.$ BmimNTf $\left._{2}\right) /$ carbon nanotube (CNT) on surface of glassy carbon (GC) electrode. Recent studies shows utilization of ionic liquid could improved the stability of biosensor, by modifying electrode with IL as one of components with other substance such as polymer, metal nanoparticles or carbon nanoparticles. It provides strong interaction between these substances and IL components that could result in stable electrode formation and decrease their aggregation enhancing their electrocatalytic reactivity. Therefore, the mixture of lipase and ionic liquid was immobilized on screen printed carbon electrodes (SPCE) in the development of triglyceride biosensor for determination of lipase activity. Chemical reactions involved in the principle of this method is as equations below Panky et al. 2013:

\section{Lipase}

Triglyceride $+\mathrm{H} 2 \mathrm{O} \rightarrow$ Glycerol +3 Fatty acid $+3 \mathrm{H}+(1)$

The advantage of using ionic liquid is that it do not denatured enzyme. ${ }^{5}$ Here, we report an electronalytical detection of triglyceride concentrations in olive oil using modified screen printed electrodes (SPE) with Ionic Liquid [1-(2-ethoxyethyl)-1-methylpyrrolidinium bis(trifluoromethylsulfonyl)imide]-lipase. $\quad\left[\mathrm{C}_{2} \mathrm{OC}_{2} \mathrm{C}_{1}\right.$ pyrr $]\left[\mathrm{N}(\mathrm{Tf})_{2}\right]-$ GA-Lipase film modified electrode has been studied against tributyrin 
$\left(\mathrm{C}_{15} \mathrm{H}_{26} \mathrm{O}_{6}\right)$ using cyclic voltamogram technique in phosphate buffer solution (PBS) as an electrolyte medium. Tributyrin was used as triglyceride substrate for hydrolysation of lipase enzyme due to its small size compared to other triglyceride structure. ${ }^{7}$ The use of ionic liquid accelerated electron transfer process at the working electrode.

\section{Experimental}

\section{Materials and instrumentations}

Lipase (L1754-10G from Candida rugosa) with specific activity of 847 Umg-1 and tributyrin (purity $98 \%$ ) were obtained from Acros Organics (USA). Lipase was dissolved in 50mM pH 7 PBS (Phosphate buffer solution) to make 5\% (wt/v) lipase solution and was stored at $4^{\circ} \mathrm{C}$. All chemicals used were of analytical grade. PBS was freshly prepared before each experiment. Scanning electron microscopy (SEM) was performed using Carlzeiss Supra 40VP SEM (Germany). Cyclic voltammetry (CV) experiments were conducted using a potentiostat PGSTAT204 Autolab, Metrohm (Netherlands) electrochemical system controlled by NOVA 1.9 software. Screen printed electrodes (SPEs) were obtained from Quasense (Thailand).

\section{Synthesis of I-(2-ethoxy-ethyl)-I-methylpyrrolidinium bis(trifluoromethylsulfonyl)imide, $\quad\left[\mathrm{C}_{2} \mathrm{OC}_{2} \mathrm{C}_{1}\right.$ pyrr $]$ [N(Tf) $]$ :}

Lithium bis(trifluoromethylsulfonyl)imide $\quad(143.54 \mathrm{~g}, \quad 0.5 \mathrm{~mol})$ was added to a solution of $\left[\mathrm{C}_{2} \mathrm{OC}_{2} \mathrm{C}_{1}\right.$ pyrr $] \mathrm{Cl}(69.28 \mathrm{~g}, 0.35 \mathrm{~mol})$ in dichloromethane $(100 \mathrm{~mL})$. The mixture was stirred for 48 hours, and then filtered. The residual salt was washed with dichloromethane $(2 \times 30 \mathrm{~mL})$ and the organic extracts were combined. The organic extract was washed with water until the aqueous phase was halide free (silver nitrate test). The solvent was removed by evaporation. The resulting liquid was stirred with activated charcoal for 24 hours. After removal of the charcoal by filtration through a glass fiber membrane, the ionic liquid was dried in vacuum at $45^{\circ} \mathrm{C}$ for 48 hours to give 1-(2-ethoxyethyl)-1-methylpyrrolidinium bis(trifluoromethylsulfonyl)imide $(97.2 \mathrm{~g}, 72 \%)$ as a colorless liquid.

Screen printed carbon electrodes (SPCE): The screen printed carbon electrodes are composed of a two-electrode system in which the carbon was employed as a working electrode and silver/silver chloride as a reference electrode. Carbon coated working electrode on surface of screen printed electrode (SPE) is $0.30 \mathrm{~cm}$ (length) $\times 0.10 \mathrm{~cm}$ (width) $\left(\right.$ area $\left.=0.03 \mathrm{~cm}^{2}\right)$.

Construction of $\left.\left[\mathrm{C}_{2} \mathrm{OC}_{2} \mathrm{C}_{1} \text { pyrr][N(Tf) }\right)_{2}\right]-G A$-lipase electrode: Lipase was immobilized using glutaraldehyde (GA) cross-linking by mixing $10 \mu \mathrm{L}$ of $5 \%$ lipase solution (in $50 \mathrm{mM}$ phosphate buffer solution (PBS) $\mathrm{pH} 7 ; 1 \mu \mathrm{L}$ of $23 \%$ glutaraldehyde, GA solution (in water); $2 \mu \mathrm{L}$ of 1- (2-ethoxy-ethyl)-1-methylpyrrolidinium bis (trifluoromethylsulfonylimide), $\left[\mathrm{C}_{2} \mathrm{OC}_{2} \mathrm{C}_{1}\right.$ pyrr $]\left[\mathrm{N}(\mathrm{Tf})_{2}\right]$ solution (in $50 \mathrm{mM}$ phosphate buffer solution (PBS) $\mathrm{pH} 7$ ), was used. Then, $2 \mu \mathrm{L}$ of mixture was dropped on the surface of SPCE, and allowed to dry at $4^{\circ} \mathrm{C}$ overnight.

Cyclic voltammetry (CV): The electrochemical response (currentvoltage) of the $\mathrm{C} /\left[\mathrm{C}_{2} \mathrm{OC}_{2} \mathrm{C}_{1}\right.$ pyrr $]\left[\mathrm{N}(\mathrm{Tf})_{2}\right]$-GA-Lipase electrode was investigated towards tributyrin $(2.0 \mathrm{mM})$ using cyclic voltammetry (CV) technique at $100 \mathrm{mVs}^{-1}$ scan rate and potential range from -1.0 to $+1.0 \mathrm{~V}$ in PBS. All electrochemical experiments have been performed at room temperature $\left(25^{\circ} \mathrm{C}\right)$ with $50 \mathrm{mM}$ PBS $(50 \mathrm{mM}, \mathrm{pH}$ 7). Electrochemical measurements were carried out in an air tight beaker containing PBS $(5 \mathrm{~mL})$.
Gas chromatography analysis: A split injection with a ratio of 1:50 was used and a sample volume injection of $1 \mu \mathrm{L}$. The sample volume injection was $1 \mu 1$. The analytical column used was BP5MS $(0.25 \mathrm{~mm}$, I.D) capillary column; maximum temperature $330^{\circ} \mathrm{C}$. The $\mathrm{GC}$ oven temperature was programmed from $50^{\circ} \mathrm{C}$ hold $1 \mathrm{~min}, 15^{\circ} \mathrm{C}$ min- 1 at $180^{\circ} \mathrm{C}$ hold $9 \mathrm{~min}, 7^{\circ} \mathrm{C}$ min- 1 at $230^{\circ} \mathrm{C}$ hold $7 \mathrm{~min}$. The injection port was held isothermally at $200^{\circ} \mathrm{C}$. Helium was used as the carrier gas and its flow rate was setup to $1 \mathrm{~mL}$ min- 1 at 10 psi.

Fourier Transform Infra Red (FTIR) was employed to investigate the characteristic functional groups of the synthesized ionic liquid $\left[\mathrm{C}_{2} \mathrm{OC}_{2} \mathrm{C}_{1}\right.$ pyrr $]\left[\mathrm{N}(\mathrm{Tf})_{2}\right]$. A characteristic signal for a $\mathrm{C}-\mathrm{H}$ functional groups were observed at 2983 and 2883 vmax cm-1 for $\mathrm{CH} 2$ at 1462 vmax cm-1 , 1131 vmax cm-1 for F-C-F, 1051 vmax cm-1 for C-F and also a signal for $\mathrm{S}=\mathrm{O}$ at 1348 vmax $\mathrm{cm}-1$ respectively. The elemental analysis composition of the ionic liquid was characterised using CHNS Elemental Analyzer. Percentage of the carbon, C, hydrogen, $\mathrm{H}$ and also Nitrogen, $\mathrm{N}$, which contained in the $\left[\mathrm{C}_{2} \mathrm{OC}_{2} \mathrm{C}_{1}\right.$ pyrr $]\left[\mathrm{N}(\mathrm{Tf})_{2}\right]$ compound was elucidated and possessed the same value as the theoretical value which was calculated based on the molecular weight of the ionic liquid compound. Figure 1 show the structure of IL.

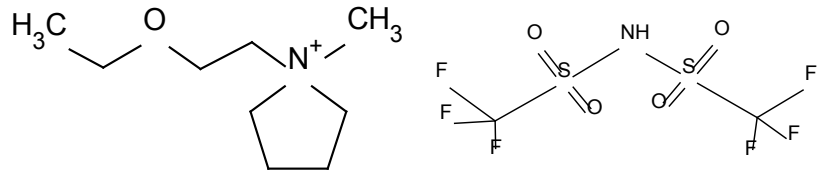

Figure I Structure of cation and anion in IL I-(2-ethoxy-ethyl) - I-methylpyrrolidinium bis(triflourosulfonyl)imide.

Cyclic voltammetry (CV) analysis w as carried out to investigate the electrochemical mechanism between the IL and the electrode surface and to note the effect of different active layers on SPCE surface. Previous studies has utilized cetyltrimethyl ammonium bromide, CTAB was used as binder on surface of SPCE. ${ }^{8}$ Current study utilized of glutaraldehyde, GA as enzyme cross linker in $\left[\mathrm{C}_{2} \mathrm{OC}_{2} \mathrm{C}_{1}\right.$ pyrr $]\left[\mathrm{N}(\mathrm{Tf})_{2}\right]$-GA-Lipase bioelectrode. The electrode that contained $\left[\mathrm{C}_{2} \mathrm{OC}_{2} \mathrm{C}_{1}\right.$ pyrr] $\left[\mathrm{N}(\mathrm{Tf})_{2}\right]$-GA-Lipase produced the highest current density $\left(400 \mu \mathrm{Acm}^{-2}\right)$ as compared to the substrate containing cetyl trimethyl ammonium bromide, CTAB $\left(198 \mu \mathrm{A} \mathrm{cm}{ }^{-2}\right)$. This is due to the denaturation of lipase enzyme, cationic detergents such as $\mathrm{CTAB}$ have been previously reported to cause denaturation of enzymes. ${ }^{9}$ It is important to note that when glutaraldehyde (GA) was added into the IL with the enzyme lipase, we obtained the highest current, this is due to the interaction between lipase enzyme and glutaraldehyde (GA) acts as cross linker that hold the lipase enzyme to the surface of electrode, therefore the stability of enzyme could be increase and higher current was produced. Comparison of two different cation of the applied IL was determined in this work by replacing cation 1-(2-ethoxy-ethyl)-1-methylpyrrolidinium, $\quad\left[\mathrm{C}_{2} \mathrm{OC}_{2} \mathrm{C}_{1}\right.$ pyrr]+ with 1-methyl-1-pentyl pyrrolidinium $\left[\mathrm{C}_{5} \mathrm{C}_{1}\right.$ pyrr $]+$. From results it shows that $\left[\mathrm{C}_{2} \mathrm{OC}_{2} \mathrm{C}_{1}\right.$ pyrr $]+$ cation produced higher current density than $\left[\mathrm{C}_{5} \mathrm{C}_{1}\right.$ pyrr $]+$ cation. This is due to the electrochemical window $(\mathrm{EW})$ of $\left[\mathrm{C}_{5} \mathrm{C}_{1}\right.$ pyrr $]$ was lower $(3 \mathrm{~V})$ than $\left[\mathrm{C}_{2} \mathrm{OC}_{2} \mathrm{C}_{1}\right.$ pyrr $](5 \mathrm{~V})$ From previous study, it stated that increase in water contain in ionic liquid cause lower in electrochemical window, (EW) due to the undesired cathodic reactions was enhanced, hence it would reduce the current efficiency of cathodic processes. ${ }^{10}$

The TG bioelectrode response best at $\mathrm{pH} 7$ of PBS solution at room temperature. to $5 \%$ of lipase concentration. Enzyme-substrate reaction was observed through variations of tributyrin concentrations ( 0 to $4.0 \mathrm{mM}$ ) spiked on biosensor that was immersed in $5 \mathrm{~mL}$ PBS 
solution. The calibration curve was plotted and a linear relationship of tributyrin concentration towards current density response was obtained $\left(\mathrm{y}=16.067 \mathrm{x}+0.2897, \mathrm{R}^{2}=0.972\right.$. The Michelis Menten parameters obtained were $\mathrm{V}_{\text {max }}=27.62 \pm 0.64 \mu \mathrm{Acm}^{-2}$ and $\mathrm{K}_{\mathrm{M}}=0.78 \pm 0.35$ $\mathrm{mM}$. Concentration of triglyceride in olive oil samples was determined $(1.64 \pm 0.45, \mathrm{n}=3, \mathrm{mM})$ using biosensor. Determination of triglyceride has been validated using gas chromatography analysis. The GC calibration curve of tributyrin showed a linear response towards tributyrin concentration with $\mathrm{y}=1.8362 \mathrm{x}-1.7618, \mathrm{R}_{2}=0.9419$. Tributyrin concentration from GC analysis in olive oil sample was 1.47 $\mathrm{mM}$, which is $89.63 \%$ accurate to the value obtained from developed biosensor. The electrode was tested free from other interference species namely ascorbic acid, glycerol, uric acid and butyric acid. It was able to produce constant current reading with relative standard deviation (\%RSD) $84 \% \pm 7.51, \mathrm{n}=3$ which shows good reproducibility of $\mathrm{C} /$ $\left[\mathrm{C}_{2} \mathrm{OC}_{2} \mathrm{C}_{1}\right.$ pyrr $]\left[\mathrm{N}(\mathrm{Tf})_{2}\right]$-GA-Lipase biosensor developed.

\section{Acknowledgements}

$1-(2-$ e thoxy - e thy 1$)-1-$ methylpyrrolidinium bis(trifluoromethylsulfonyl)imide was synthesized by Dr Mohd Azri Ab Rani (Faculty of Applied Sciences, UniversitiTeknologi MARA, 40450 Shah Alam, Selangor, Malaysia). Financial and technical support from The Ministry of Higher Education under Research Acculturation Grant Scheme (RAGS) 600-RMI/RAGS 5/3 (31/2013) and Universiti Teknologi MARA (UiTM) are highly acknowledged.

\section{Conflict of interest}

The author declares no conflict of interest.

\section{References}

1. Narang J, Minakshi, Bhambi M, et al. Determination of serum triglyceride by enzyme electrode using covalently immobilized enzyme on egg shell membrane. Int J Biol Macromol. 2010;47(5):691-695.
2. Phongphut, Sriprachuabwong C, Wisitsoraat A, et al. A disposable amperometric biosensor based on inkjet-printed Au/PEDOT-PSS nanocomposite for triglyceride determination. Sensors and Actuators B: Chemical. 2013;178:501-507.

3. Pundir CS, Sandeep Singh B, Narang J. Construction of an amperometric triglyceride biosensor using PVA membrane bound enzymes. Clin Biochem. 2010;43(4-5):467-472.

4. Pundir CS, Narang J. Determination of triglycerides with special emphasis on biosensors: a review. Int J Biol Macromol. 2013;61:379389.

5. Pauliukaite R, Doherty AP, Murnaghan KD, et al. Application of room temperature ionic liquids to the development of electrochemical lipase biosensing systems for water-insoluble analytes. Journal of Electroanalytical Chemistry. 2011;656(1-2):96-101.

6. Solanki, Pratima R, Dhand Chetna, et al. Nanostructured cerium oxide film for triglyceride sensor. Sensors and Actuators B: Chemical. 2009;141(2):551-556.

7. Setzu S, Salis S, Demontis V, et al. Porous silicon-based potentiometric biosensor for triglycerides. Application and material science. 2007;204(5):1434-1438.

8. Ahmad NM, Abdullah J, Ramli NI, et al. An approach of $\mathrm{ZrO}$ PEG nanocomposite film on screen printed carbon electrode and its application in Glucose determination. 2014. p. 1-7.

9. Shanmugam S. Enzyme technology. India: IK International Publishing House; 2009 p. 24.

10. Hayyan A, Mjalli FS, Hashim MA, et al. Ethanesulfonic acid-based esterification of industrial acidic crude palm oil for biodiesel production. Bioresour Technol. 2011;102(20):9564-9570. 